\title{
Phytochemical and Pharmacological Properties of Capparis spinosa as a Medicinal Plant
}

\author{
Hongxia Zhang ${ }^{1, *,+}$ and Zheng Feei Ma ${ }^{2, *,+}$ iD \\ 1 Department of Food Science, University of Otago, Dunedin 9054, New Zealand \\ 2 Department of Public Health, Xi'an Jiaotong-Liverpool University, Suzhou 215123, China \\ * Correspondence: zhanghongxia326@hotmail.com (H.Z.); Zhengfeei.Ma@xjtlu.edu.cn (Z.F.M.); \\ Tel.: +64-3-470-9198 (H.Z.); +86-512-8188-4938 (Z.F.M.) \\ + These two authors contributed equally to the manuscript as the first co-authors.
}

Received: 29 November 2017; Accepted: 19 January 2018; Published: 24 January 2018

\begin{abstract}
Over the past decades, there has been increasing attention on polyphenol-rich foods including fruits and vegetables on human health. Polyphenols have been shown to possess some potential beneficial effects on human health and they are widely found in foods consumed by populations worldwide. Capparis spinosa (C. spinosa) is an important source of different secondary metabolites of interest to humankind. The traditional therapeutic applications of $C$. spinosa have been reported in Ancient Romans. Numerous bioactive phytochemical constituents have been isolated and identified from different parts (aerial parts, roots and seeds) of C. spinosa which are responsible alone or in combination for its various pharmacological activities. Therefore, this paper is a review of publications on the phytochemical and pharmacological properties of $C$. spinosa. There is insufficient evidence to suggest that $C$. spinosa or its extracts are able to improve the biomarkers of cardiovascular disease and diabetes. However, these studies used different parts of C. spinosa plant, methods of preparation and types of solvents, which cause the evaluation of activity of $C$. spinosa difficult and involve quite heterogeneous data. There is also evidence, although limited, to suggest benefits of C. spinosa in improving human health. Therefore, the relationship between C. spinosa and improved human health outcomes requires further study.
\end{abstract}

Keywords: Capparis spinosa; caper; cardiovascular disease; traditional medicine; flavonoids; rutin

\section{Introduction}

Medicinal plants have been used since ancient times as therapeutic agents for the management of health and treatment of diseases because they possess health-promoting effects and contain bioactive components [1]. According to the World Health Organization (WHO) [2], 80\% of the world's populations rely mainly on traditional medicine. In China, $30-50 \%$ of the overall medicinal consumption is estimated from the preparations of traditional medicine [3]. Approximately $90 \%$ of the population in Germany reported that they have used natural remedies for certain health purposes [2]. Therefore, there is increasing use and popularity of traditional medicine in both the developing and industrialized countries [4], demonstrating that the global market for traditional medicine continues to be strong. The international market for herbal medicines has hit over $\$ 60$ billion yearly and it continues to increase gradually [4]. Therefore, medicinal plants such as Capparis spinosa (C. spinosa) continue to play a major role in healthcare systems [4].

C. spinosa is one of the most important economical species in the Capparidaceae family which has a wide range of diversity (i.e., about 40-50 genera and 700-900 species) [5]. Capparidaceae has been known to be closely related to the family of the Brassicaceae (Cruciferae) that is rich in glucosinolates and flavonoids [5]. C. spinosa is also known as Caper, wild watermelon (in China) [6], Cappero (in Italy), 
Alaf-e-Mar (in Persian) [7] and Alcapparo (in Spain) [8]. C. spinosa is a dicotyledonous perennial shrub which can grow up to $1 \mathrm{~m}$ high and has extensive root systems [9]. It is native to the Mediterranean basin and widely distributed from Morroco to Crimea, Armernia, Iran [10]. Several countries such as Greece, Italy, Spain and Turkey have widely produced C. spinosa [11]. For example, Spain and Turkey produce about 1000 and 4500 tonnes of C. spinosa a year, respectively [8].

Few articles [12,13] have reviewed some of the chemical compounds and health benefits of C. spinosa in different aspects including its potential for sustainability. Therefore, the aim of our work was to summarise and review the phytochemical of $C$. spinosa including aerial parts, roots and seeds with reference to their pharmacological activity shown in animal and human studies. In addition, our work has also added significantly to the current understanding of the bioactive compounds isolated from the roots and seeds of C. spinosa, which has not been adequately covered in the previous literature reviews.

\subsection{Search Strategy}

An electronic literature search was conducted using Cochrane Library, PubMed, Medline (OvidSP) and Google Scholar until October 2017. Additional references were hand-searched. Search terms included combinations of the following using Boolean markers: Capparis spinosa, C. spinosa, Capparis, caper, phytochemical, pharmacological and antioxidant. The search was restricted to English language publications that addressed the phytochemical constituents and/or pharmacological properties of C. spinosa.

\subsection{Taxonomic Revision of Genus Capparis}

There are 813 plant name records that matched Capparis in the plant database 'The Plant List' (at http:/ / www.theplantlist.org). When C. spinosa was searched in the same database, 22 plant name records were found. There have been 250 different species in the genus of Capparis which are recognized morphologically. However, the use of morphological markers of the Capparis species has its limitations in defining the subspecies and varieties because of the free hybridization of different Capparis species and the presence of their intermediate forms [14]. Therefore, the classification of Capparis remains to be very ambiguous and controversial [15]. Aichi-Yousfi et al. [16] demonstrated that the use of amplified fragment length polymorphism (AFLP) analysis was efficient to make definitive discrimination among the genetic diversity and relationship between various species of Capparis. The authors used three primer combinations of AFLP markers to genotype 213 Capparis accessions belonging to six Tunisian Capparis species [16].

\subsection{Cultivation of C. spinosa}

C. spinosa which is an aromatic plant is usually cultivated in tropical and subtropical regions [10]. The most common propagation of C. spinosa is vegetative cuttings [10]. It can flourish under dry hot conditions in either well-drained or poor soils. In addition, C. spinosa is salt tolerant and resistant to drought [17]. Although C. spinosa can be grown in a wide range of environmental conditions, it is generally grown on sandy loam soils with low alkalinity [18]. It grows and flowers from May to October covering the summer drought [19]. Since it has deep, extensive root systems and can be grown in harsh environments, it has been recommended for the prevention of land degradation and soil erosion control [17].

\subsection{Traditional Uses of C. spinosa}

Different parts of $C$. spinosa including fruits and roots have been used as a traditional herbal remedy since ancient times for its beneficial effects on human diseases [20]. Ancient Egypt and Arab consumed the roots of C. spinosa to treat liver and kidney diseases; Ancient Romans used C. spinosa for the treatment of paralysis; Moroccans used C. spinosa to treat diabetes [8]. In the Northern areas of Pakistan, the root barks of $C$. spinosa have been used to treat splenomegaly, mental disorders 
and tubercular glands [21]. In China, C. spinosa has been used in traditional Uighur Medicine for the treatment of rheumatoid arthritis and gout [6]. In Iran, C. spinosa is used to treat hemorrhoids and gout [22]. Table 1 shows the main traditional uses of $C$. spinosa used to ease symptoms and treat diseases.

Table 1. Main traditional uses of Capparis spinosa (C. spinosa) to ease symptoms and treat diseases.

\begin{tabular}{c}
\hline Treated Symptoms and Diseases \\
\hline Toothache \\
Fever \\
Headache \\
Menstruation \\
Rheumatism \\
Convulsions \\
Gout \\
Skin disease \\
Kidney disease \\
Liver disease \\
Diabetes \\
Hemorhoids \\
Ulcers \\
Sciatica
\end{tabular}

\section{Phytochemical Properties of C. spinosa}

Since $C$. spinosa has several beneficial health effects on human diseases, the chemical and bioactive components of $C$. spinosa have been extensively investigated and reported by numerous analytical studies [11,23-36]. Table 2 demonstrates the important constituents isolated from C. spinosa. These studies have focused on the bioactive compounds of different parts of C. spinosa such as leaves [27,37], buds [11], fruits [23-26], roots [31-33] and seeds [34-36]. In general, C. spinosa has a wide range of bioactive compounds such as alkaloids, flavonoids, streroids, terpenoids and tocopherols [38].

Since C. spinosa is rich in flavonoids, many studies have identified and quantified flavonoids found in C. spinosa. Flavonoid compounds such as rutin and quercertin are detected in C. spinosa [39]. Flavonoids have received considerable attention for their positive effects on health because of their anti-oxidative property [40]. Flavonoids are hydroxylated phenolic compounds and are found in plants [39]. Flavonoids have a 15-carbon skeleton, which consists of two benzene rings and a heterocyclic pyrane ring [41]. Flavonoids can be divided into several classes based on their structures such as flavones, flavonols, flavanones, isoflavonoids and others [41]. The consumption of flavonoids is suggested to reduce the risk of cardiovascular disease (CVD) and promote human health [41]. Rutin strengthens capillaries and inhibit platelet clump formation in the blood vessels due to its high radical scavenging and antioxidant properties [42]. In addition, rutin reduces low density lipoprotein (LDL) cholesterol level, which is associated with improve CVD risk biomarkers [43]. Quercetin has been linked with a reduced risk of CVD because of its anti-hypertensive and anti-platelet aggregating properties [44].

\subsection{Aerial Parts}

Most of the isolation and identification of alkaloids and related compounds have been focused on the fruits of C. spinosa. A study by Fu et al. [23] reported that the fruits of C. spinosa were shown to contain Cappariloside A, stachydrin, hypoxanthine and uracil. Another study by Çaliş et al. [25] reported that two glucose-containing $1 \mathrm{H}$-indole-3-acetonitrile compounds, $1 \mathrm{H}$-indole-3-acetonitrile 4-O- $\beta$-(6'-O- $\beta$-glucopyranosyl)-glucopyranoside and $1 \mathrm{H}$-indole-3-acetonitrile 4 - $O$ - $\beta$-glucopyranoside were identified from mature fruits of $C$. spinosa using spectroscopic methods. In addition, capparine $A$, capparine B, flazin, guanosine, $1 H$-indole-3-carboxaldehyde, 4-hydroxy- $1 H$-indole-3-carboxaldehyde 
apigenin, kaempferol and thevetiaflavone were identified in the fruits of $C$. spinosa [26]. There are also other new identified alkaloids including capparisine $A$, capparisine $B$, capparisine $C$ that were also isolated from the fruits of C. spinosa [45]. Tetrahydroquinoline acid was isolated from the fruits and stems of $C$. spinosa using column chromatorgraphy [46].

Table 2. Summary of some important constituents isolated from C. spinosa.

\begin{tabular}{|c|c|c|c|}
\hline $\begin{array}{l}\text { Parts of } C \text {. spinosa } \\
\text { Plant }\end{array}$ & Compounds Identified & Extraction Method & References \\
\hline \multirow{13}{*}{ Aerial parts } & $\begin{array}{l}\text { Cappariloside A } \\
\text { Stachydrin } \\
\text { Hypoxanthine } \\
\text { Uracil }\end{array}$ & $\begin{array}{l}\text { Chromatographic } \\
\text { method }\end{array}$ & Fu et al. (2007) [23] \\
\hline & $\begin{array}{c}1 H \text {-indole-3-acetonitrile } \\
\text { 4-O- } \beta \text {-(6-O- } \beta \text {-glucopyranosyl)-glucopyranoside } \\
1 H \text {-indole-3-acetonitrile } 4-O-\beta \text {-glucopyranoside } \\
\text { Indole-3 acetonitrile glycosides }\end{array}$ & Spectroscopic method & Çaliş et al. (1999) [25] \\
\hline & $\begin{array}{c}\text { Capparine A } \\
\text { Capparine B } \\
\text { Flazin } \\
\text { Guanosine } \\
1 H \text {-indole-3-carboxaldehyde } \\
\text { 4-hydroxy-1H-indole-3-carboxaldehyde } \\
\text { Apigenin } \\
\text { Kaempferol } \\
\text { Thevetiaflavone }\end{array}$ & Spectroscopic method & Zhou et al. (2010) [26] \\
\hline & $\begin{array}{l}\text { Capparisine A } \\
\text { Capparisine B } \\
\text { Capparisine C }\end{array}$ & $\begin{array}{l}\text { Chromatographic } \\
\text { method }\end{array}$ & Yang et al. (2010) [45] \\
\hline & $\begin{array}{c}\text { Tetrahydroquinoline } \\
\text { Benzofuranone enantiomers 2-(4-hydroxy-2-oxo-2,3- } \\
\text { dihydrobenzofuran-3-yl)acetonitrile }\end{array}$ & $\begin{array}{l}\text { Chromatographic } \\
\text { method }\end{array}$ & Zhang et al. (2014) [46] \\
\hline & Rutin & $\begin{array}{l}\text { Chromatographic } \\
\text { method }\end{array}$ & Mollica et al. (2017) [37] \\
\hline & $\begin{array}{l}\text { Kaempferol-3-glucoside } \\
\text { Kaempferol-3 rutinoside } \\
\text { Kaempferol-3-rhamnorutinoside }\end{array}$ & $\begin{array}{l}\text { Chromatographic } \\
\text { method }\end{array}$ & Rodrigo et al. (1992) [28] \\
\hline & $\begin{array}{l}\text { Kaempferol 3-O-rutinoside } \\
\text { Isorhamnetin 3-O-rutinoside }\end{array}$ & $\begin{array}{l}\text { Chromatographic } \\
\text { method }\end{array}$ & Siracusa et al. (2011) [29] \\
\hline & $\begin{array}{l}\text { Quercetin 3-O-glucoside } \\
\text { Quercetin 3-O-glucoside-7-O-rhamnoside } \\
\text { Quercetin 3-O-[6"' } 6^{\prime \prime \prime}-\alpha \text {-L-rhamnosyl-6"- } \beta \text {-D- } \\
\text { glucosyl]- } \beta \text {-D-glucoside }\end{array}$ & $\begin{array}{l}\text { Chromatographic } \\
\text { method }\end{array}$ & Sharaf et al. (2000) [30] \\
\hline & $\begin{array}{l}\text { Kaempferol 3-rhamnosyl-rutinoside } \\
\text { Kaempferol 3-rutinoside } \\
\text { Quercetin 3-rutinoside }\end{array}$ & $\begin{array}{l}\text { Chromatographic } \\
\text { method }\end{array}$ & Inocencio et al. (2000) [11] \\
\hline & $\begin{array}{c}\text { Ginkgetin } \\
\text { Isoginkgetin } \\
\text { Sakuranetin } \\
\text { Quercetin-3-O-rutinoside }\end{array}$ & Spectroscopic method & Zhou et al. (2011) [47] \\
\hline & Quercetin-7-rutinoside & $\begin{array}{l}\text { Chromatographic } \\
\text { method }\end{array}$ & Sharaf et al. (1997) [48] \\
\hline & Glucocapparin & $\begin{array}{l}\text { Chromatographic } \\
\text { method }\end{array}$ & $\begin{array}{l}\text { Matthaus \& Ozcan } \\
\text { (2002) [49] }\end{array}$ \\
\hline \multirow{3}{*}{ Roots } & $\begin{array}{c}\text { Capparispine } \\
\text { Cadabicine 26-O- } \beta \text {-D-glucoside } \\
\text { Capparispine 26-O- } \beta \text {-D-glucoside }\end{array}$ & Spectroscopic method & Fu et al. (2008) [27] \\
\hline & Stachydrine & $\begin{array}{l}\text { Chromatographic } \\
\text { method }\end{array}$ & Khatib et al. (2016) [32] \\
\hline & $\begin{array}{l}\text { 3-hydroxy-7-methoxy-2-methyl-4H-1,4-benzoxazine- } \\
\text { 4-carbaldehyde }\end{array}$ & $\begin{array}{l}\text { Chromatographic } \\
\text { method }\end{array}$ & Boga et al. (2011) [33] \\
\hline Seeds & Glucocapparin & $\begin{array}{l}\text { Chromatographic } \\
\text { method }\end{array}$ & $\begin{array}{l}\text { Matthaus \& Ozcan } \\
\text { (2002) [49] }\end{array}$ \\
\hline
\end{tabular}


Rodrigo et al. [28] reported that fresh C. spinosa were shown to contain rutin, kaempferol-3-glucoside, kaempferol-3 rutinoside and kaempferol-3-rhamnorutinoside. Of these flavonoids, rutin was the most abundant [28]. Ramezani et al. [27] reported that the content of rutin in fruits, flowers and leaves of $C$. spinosa was $6.03,43.72$ and $61.09 \mathrm{mg} / 100 \mathrm{~g}$ of dried powder, respectively. It is suggested that rutin may be beneficial to health including cardio-protective versatile, cholesterol-lowering, anti-cancer and anti-inflammatory.

A study by Siracusa et al. [29] reported that rutin, kaempferol 3-O-rutinoside and isorhamnetin 3-O-rutinoside were isolated from wild-grown C. spinosa using High-Performance Liquid Chromatography/Ultraviolet-Visible-Diode Array Spectroscopy/Electrospray Ionization-Mass Spectrometry (HPLC/UV-Vis-DAD/ESI-MS). The authors reported that about half of the total amount of phenolic compounds was rutin (quercetin-3-O-rutinoside) followed by kaempferol 3-O-rutinoside [29].

In addition, other flavonoids such as quercetin 3-O-glucoside, quercetin 3-O-glucoside-7$O$-rhamnoside, quercetin 3-O-[6 $6^{\prime \prime \prime}-\alpha$-L-rhamnosyl- $6^{\prime \prime}-\beta$-D-glucosyl $]-\beta$-D-glucoside were also identified in the aerial parts of C. spinosa [30]. Another study by Zhou et al. [47] reported that ginkgetin, isoginkgetin, sakuranetin, kaempferol-3-O-rutinoside and quercetin-3-O-rutinoside were isolated in fruits of $C$. spinosa. The authors also reported that ginkgetin, isoginkgetin and sakuranetin were the first time to be identified in fruits of C. spinosa [47]. It is suggested that ginkgetin and isoginkgetin may have anti-inflammatory and neuroprotective effects. A study by Sharaf et al. [48] demonstrated that kaempferol-3-rutinoside, quercetin-3-rutinoside, quercetin-7-rutinoside, quercetin 3-glucoside-7-rhamnoside were isolated in stems and leaves of $C$. spinosa.

Afsharypuor et al. [31] reported that leaves and ripe fruits of C. spinosa contained the glucosinolates degradation products which were methyl, isopropyl and set-butyl isothiocyanates. Glucosinolates are secondary plant metabolites that are of pharmacological interest because they may have a role in the prevention of diseases and reducing the risk of carcinogenesis. Similarly, Çaliş et al. [25] also reported that indole- 3 acetonitrile glycosides was detected in fruits of $C$. spinosa.

Some studies also investigated the flavonoids in flower buds of $C$. spinosa [11,49]. Inocencio et al. [11] used HPLC coupled with a diode-array detector to isolate kaempferol 3-rhamnosyl-rutinoside, kaempferol 3-rutinoside and quercetin 3-rutinoside from the flower buds of C. spinosa. The authors reported that rutin (quercetin-3-O-rutinoside) was the most abundant compound followed by kaempferol 3-rutinoside [11]. Also, they found that $10 \mathrm{~g}$ of C. spinosa would provide approximately $65 \mathrm{mg}$ of flavonoid glycosides [11]. The main glucosinolates in shoots and buds of C. spinosa was glucocapparin, which contributed $90 \%$ of the total glucosinolates [49]. It is suggested that the composition of glucosinolates may vary according to the bud size of $C$. spinosa.

Other classes of compounds such as benzofuranone enantiomers 2-(4-hydroxy-2-oxo2,3-dihydrobenzofuran-3-yl)acetonitrile were also isolated from the stems and fruits of $C$. spinosa using column chromatography [46]. Two new (6S)-hydroxy-3-oxo- $\alpha$-ionol glucosides and a prenyl glucoside were isolated from the mature fruits of $C$. spinosa using chromatographic methods [24]. In addition, $p$-hydroxybenzoic acid, vanillic acid, protocatechuric acid, butanedioic acid, uracil, uridine and daucosterol were isolated from fruit of of $C$. spinosa using chromatographic methods [50]. The $p$-methoxy benzoic acid was isolated and identified from the aerial parts of $C$. spinosa using Nuclear Magnetic Resonance (NMR) spectroscopy [51].

In a study investigating the spontaneous volatile emission of different aerial parts of C. spinosa, Ascrizzi et al. [52] reported that 178 volatile organic compounds (VOCs) were determined by headspace solid-phase microextraction (HS-SPME) coupled with gas chromatography (GC)/MS. The major VOCs emitted by leaves of $C$. spinosa were germacrene D $(20 \%)$ and decanal $(15 \%)$ [52]. The flower bud of C. spinosa mainly emitted isopropyl tetradecanoate $(26 \%),(E)$-nerolidol $(17 \%)$ and hexahydrofarnesyl acetone (11\%) [52]. For the fruits of C. spinosa, the majority of the VOCs were $\beta$-caryophyllene $(40 \%)$, $\alpha$-guaiene (12\%), bicyclogermacrene (11\%) and macrene B (8\%) [52]. 


\subsection{Roots}

Limited studies have been focused on the isolation and identification of bioactive compounds from the roots of $C$. spinosa. Similar to leaves and fruits of $C$. spinosa, the roots of $C$. spinosa were shown to contain glucosinolates degradation products including methyl, isopropyl and set-butyl isothiocyanates [31]. Fu et al. [53] isolated several new spermidine alkaloids (i.e., capparispine, cadabicine $26-O-\beta$-D-glucoside and capparispine $26-O-\beta$-D-glucoside) from the roots of $C$. spinosa and used NMR spectroscopy to establish their structures. Stachydrine [32] and 3-hydroxy-7-methoxy2-methyl-4H-1,4-benzoxazine-4-carbaldehyde [33] were also determined from the roots of C. spinosa using proton $\left({ }^{1} \mathrm{H}\right) \mathrm{NMR}$.

\subsection{Seeds}

Ascrizzi et al. [52] reported that the seeds of C. spinosa emitted $99 \%$ of the total emission profile were sesquiterpene hydrocarbons with the most abundant compounds being $\beta$-caryophyllene $(45 \%)$ followed by $\alpha$-guaiene (15\%), bicyclogermacrene $(12 \%)$ and germacrene B $(8 \%)$.

Similar to roots of $C$. spinosa, less attention has been devoted to the seeds of $C$. spinosa. The total content of glucosinolates in seeds of C. spinosa (dry weight basis) ranged from 42.6 to $88.9 \mu \mathrm{mol} / \mathrm{g}$ and more than $95 \%$ of the total amount of glucosinolates was glucocapperin [36], which is similar to main glucosinolates in shoots and buds of $C$. spinosa. The seeds of $C$. spinosa are also a potential important source of oils for industrial, nutritional and pharmaceutical purposes. The oil content of $C$. spinosa seeds ranged from 27 to $38 \mathrm{~g} / 100 \mathrm{~g}$ [36]. Three studies [34-36] have shown that the seeds of C. spinosa contained two major unsaturated fatty acids, linoleic acid (25-51\%) and oleic acid (15-37\%), which can improve cardiovascular health. In addition, the seed oils of $C$. spinosa also contain other fatty acids such as myristic acid (1\%), stearic acid (3\%), palmitic acid (12\%), palmitoleic acid (4\%), cis-vaccenic acid $(19 \%)$, linolenic acid $(1 \%)$, behenic acid $(1 \%)$, eicosenoic acid $(<1 \%)$, eicosanoic acid $(1 \%)$ and lignoceric acid $(<1 \%)$ [36].

Sterols such as stigmasterol, sitosterol, campesterol and avenasterol were also determined from the seed oils of C. spinosa [36]. The total amount of sterols in the seed oils of C. spinosa ranged from 4962 to $10,008 \mathrm{mg} / \mathrm{kg}$. In addition, the seed oils of C. spinosa are also rich in tocopherols with $\gamma$ and $\delta$ - tocopherols as the major vitamin $E$ active compounds [36]. The total amount of tocopherols in the seed oils of C. spinosa ranged from 249 to $1985 \mathrm{mg} / 100 \mathrm{~g}$ [36]. Citrostadienol, cycloartanol, gramisterol, hexadecanol, octadecanol, $\beta$-amyrin and tetracosanol were also determined from the seeds of C. spinosa [36].

\section{Pharmacological Effects of C. spinosa}

Although many studies using various parts of C. spinosa have reported diverse pharmacological activities including anti-diabetic and anti-hypertensive, there is still no conclusive information regarding the association between C. spinosa and its health benefits. This is because only a very few studies that involved human subjects examined the effect of $C$. spinosa consumption on human health. Similar to other plants $[54,55]$, although there exists literature related to the health benefits of C. spinosa, studies often infer a causal correlation between a bioactive substance of $C$. spinosa, and the observe health outcomes. This approach is likely to be an oversimplification of the complex mechanisms in the body that will eventually lead to the observed health outcomes. Therefore, the conclusions of such studies on the effects of changes in the dietary intake should be interpreted with caution because the health outcomes may not be attributed to the action of a single bioactive substance [56]. Table 3 illustrates major pharmacological effect of C. spinosa. 
Table 3. Overview on major pharmacological effects of C. Spinosa.

\begin{tabular}{|c|c|c|c|}
\hline Pharmalogical Effects & Models & $\begin{array}{l}\text { Parts of C. spinosa } \\
\text { Plant Used }\end{array}$ & References \\
\hline \multirow{4}{*}{ Anti-diabetic } & Streptozotocin-induced diabetic rats & Fruits & Eddouks et al. (2005) [57] \\
\hline & Highly glucose tolerant and high fat diet-fed mice & Fruits & Lemhadri et al. (2007) [58] \\
\hline & Type 2 diabetic patients & Fruits & Huseini et al. (2013) [59] \\
\hline & Streptozotocin-induced diabetic rats & Leaves & Mollica et al. (2017) [37] \\
\hline \multirow{2}{*}{ Anti-obesity } & Streptozotocin-induced diabetic rats & Fruits & Eddouks et al. (2005) [57] \\
\hline & Highly glucose tolerant and high fat diet-fed mice & Fruits & Lemhadri et al. (2007) [58] \\
\hline \multirow{3}{*}{ Cholesterol-lowering } & Streptozotocin-induced diabetic rats & Fruits & Eddouks et al. (2005) [57] \\
\hline & Streptozotocin-induced diabetic rats & Fruits & Jalali et al. (2016) [60] \\
\hline & Type 2 diabetic patients & Fruits & Huseini et al. (2013) [59] \\
\hline Anti-hypertensive & Spontaneously hypertensive rats & Fruits & Ali et al. (2007) [61] \\
\hline \multirow{4}{*}{ Antimicrobial } & Cell culture & Roots & Boga et al. (2011) [33] \\
\hline & Cell culture & Roots and fruits & $\begin{array}{c}\text { Mahboubi \& Mahboubi } \\
\text { (2014) }\end{array}$ \\
\hline & Cell culture & Stem barks and shoots & Gull et al. (2015) [62] \\
\hline & Cell culture & Aerial parts & Masadeh et al. (2014) [63] \\
\hline \multirow{4}{*}{ Anti-inflammatory } & Swiss albino mice & Leaves & El Azhary et al. (2017) [64] \\
\hline & Human peripheral blood mononuclear cells & Leaves & Moutia et al. (2016) [65] \\
\hline & Male Sprague-Dawley rats & Roots & Maresca et al. (2016) [66] \\
\hline & Mouse-bone marrow derived dendritic cells & Fruits & Hamuti et al. (2017) [67] \\
\hline \multirow{2}{*}{ Antihepatotoxic } & Albino rats of Wistar strain & \multirow{2}{*}{ Aerial parts } & Gadgoli \& Mishra (1999) [51] \\
\hline & Diabetic rats & & Kazemian et al. (2015) [68] \\
\hline
\end{tabular}

\subsection{Anti-Diabetic}

In a randomised, double-blind, placebo-controlled clinical trial of 54 type 2 diabetic patients, Huseini et al. [59] reported that patients who took $1200 \mathrm{mg} \mathrm{C}$. spinosa fruit extracts daily for 2 months had a significantly lower level of glycosylated hemoglobin and fasting blood glucose than the control group ( $p=0.043$ and 0.037 , respectively). The findings of their study demonstrated an improvement in hypertriglyceridemia and hyperglycemia in diabetic patients [59]. In addition, no renal and hepatic adverse events were reported in the patients [59]. The possible mechanism is that $C$. spinosa decreases the rate of carbohydrate absorption and exert its postprandial hypoglycemic effect in the gastrointestinal tract [58]. Therefore, the consumption of C. spinosa may be beneficial and safe for controlling and treating blood glucose levels in diabetic patients.

\subsection{Anti-Obesity}

Eddouks et al. [57] demonstrated that there was a significant weight loss in diabetic rats fed with the aqueous extract of powdered fruits of $C$. spinosa $(20 \mathrm{mg} / \mathrm{kg})$ after 2 weeks $(p<0.01)$. Another study by Lemhadri et al. [58] reported that repeated oral administration of aqueous extracts of $C$. spinosa was associated with a significant loss of body weight in high fat diet-fed mice after 2 weeks $(p<0.01)$. Therefore, it is suggested that $C$. spinosa may be used for weight loss management. However, further studies are needed to confirm such findings.

\subsection{Cholesterol-Lowering}

C. spinosa has been reported to be associated with improved plasma lipid parameters. Huseini et al. [59] reported a significant decrease in the triglyceride level of type 2 diabetic patients who were supplemented with $1200 \mathrm{mg} \mathrm{C}$. spinosa fruit extracts daily for 2 months $(p=0.029)$. The possible mechanism for the cholesterol-lowering effect of $C$. spinosa is that $C$. spinosa decreases the activity of 3-hydroxy-3-methyl-glutaryl coenzyme A reductase (HMG-CoA reductase), which plays an important role in the biosynthesis of cholesterol [69]. Therefore, C. spinosa may be useful for the treatment of fatty liver disease and metabolic syndrome because it plays an important role in the inhibition of gluconeogenesis in liver. 


\subsection{Anti-Hypertensive}

C. spinosa has the potential to be used for the treatment of hypertension. In a study of spontaneously hypertensive rats, Ali et al. [61] reported that when the aqueous extract of powdered fruits of C. spinosa (150 mg/kg) was administered for 20 days, the systolic blood pressure was significantly decreased after 8 days $(p<0.05), 12$ days $(p<0.01)$ and 16 days $(p<0.001)$. In addition, there was also a significant increase in the concentration of urinary sodium $(p<0.001)$, potassium $(p<0.001)$ and chloride $(p<0.001)$ after 20 days [61]. No change in heart rate was observed during the period. In addition, there was also no difference in the activity of plasma angiotensin-converting enzyme (ACE) and renin after 20 days [61]. It is suggested that C. spinosa decreases blood pressure by increasing the excretion of renal electrolytes and inhibiting the ACE activity. The inhibition of ACE activity is associated with a decrease in blood pressure [70]. Therefore, C. spinosa may play an important in the reduction of blood pressure.

\subsection{Anti-Microbial}

In a study investigating the antibacterial activity of C. spinosa, Boga et al. [33] reported that the growth rate of Deinococcus radiophilus (D. radiophilus) was significantly inhibited by the addition of aqueous extracts from roots of C. spinosa as compared to the control. However, no inhibition was shown on the growth rate of Escherichia coli (E. coli) by the addition of aqueous extracts from roots of C. spinosa [33].

Another study by Mahboubi and Mahboubi [22] evaluated the antimicrobial activity of aqueous, ethanolic, ethyl acetate and methanolic extracts of $C$. spinosa roots and fruits. The authors reported that the aqueous extracts of $C$. spinosa roots exhibited a higher antimicrobial activity against a wide range of microorganisms than that of fruit aqueous extracts of C. spinosa fruits [22]. The authors demonstrated that the aqueous extracts from roots of $C$. spinosa possessed inhibitory effect against bacteria and fungi including Staphylococcus aureus (S. aureus), Staphylococcus saprophyticus (S. saprophyticus), Staphylococcus epidermidis (S. epidermidis), Streptococcus pyogenes (S. pyogenes), Streptococcus mutans (S. mutans), E. coli, Salmonella typhimurium (S. typhimurium), Shigella dysenteriae (S. dysenteriae), Shigella flexneri (S. flexneri), Klebsiella pneumoniae (K. pneumoniae), Bacillus subtilis (B. subtilis), Bacillus cereus (B. cereus), Candida albicans (C. albicans), Candida glabrata (C. glabrata), Aspergillus flavus (A. flavus), Aspergillus parasiticus (A. parasiticus) and Aspergillus niger (A. niger) [22].

Gull et al. [62] reported that the methanolic extracts of $C$. spinosa stem barks and shoots had the greatest antibacterial activity against B. subtilis with growth inhibition zones of $26.8 \mathrm{~mm}$ and $24.6 \mathrm{~mm}$, respectively. While the methanolic extracts of $C$. spinosa fruits had the highest growth inhibition zones $(24.9 \mathrm{~mm})$ against Pasteurella multocida (P. multocida) followed by B. subtilis $(23.9 \mathrm{~mm})$, E. coli $(20.9 \mathrm{~mm})$ and $S$. aureus $(17.7 \mathrm{~mm})$ [62]. On the other hand, the highest antibacterial activity of the methanolic extracts of $C$. spinosa flowers and roots was observed against E. coli with growth inhibition zones of $26.5 \mathrm{~mm}$ and $23.9 \mathrm{~mm}$, respectively [62]. In addition, polysaccharides of C. spinosa leaves have been suggested to exhibit antimicrobial activity. Mazarei et al. [71] reported that polysaccharides of C. spinosa leaves had a higher antimicrobial activity against E. coli, S. dysenteriae and Salmonella typhi (S. typhi).

Mahasneh [72] reported that butanol extract of C. spinosa showed a moderate to good antifungal activity against $C$. albicans and $A$. flavus. In addition, ethanol extracts of $C$. spinosa exhibited weak cytotoxicity against Helicobactor pylori (H. pylori) isolates [63]. The infection of H. pylori is associated with several gastroduodenal diseases such as gastric cancer [73]. It is suggested that the method of preparing extracts and the type of solvent used may affect the microbial activity of C. spinosa.

\subsection{Anti-Inflammatory}

In an in vivo mouse model, El Azhary et al. [64] reported that Swiss albino mice treated with C. spinosa leaf extracts had a significantly reduced edema than control, demonstrating the 
anti-inflammatory activity of C. spinosa. In addition, the authors also found that C. spinosa had significantly decreased the dermis thickness and immune cell infiltration in the inflammatory site. Similarly, Moutia et al. [65] reported that C. spinosa leaf extract was shown to exhibit anti-inflammatory activity in vitro on human peripheral blood mononuclear cells (PBMC) obtained from healthy subjects. The authors also found that PBMC treated with the aqueous fraction of $C$. spinosa leaf extract had a significant increase in interleukin (IL)-4 gene expression (an anti-inflammatory cytokine) and a significant decrease in IL-17 gene expression (pro-inflammatory cytokine) [65]. Therefore, these studies suggested that $C$. spinosa leaf extracts exhibit anti-inflammatory activity by inhibiting the pro-inflammatory cytokines expression and immune cell infiltration $[64,65]$.

C. spinosa root extracts were reported to relieve pain in complete Freund's adjuvant (CFA)-induced rheumatoid arthritis and mono-iodoacetate (MIA)-induced osteoarthritis male Sprague-Dawley rats [66]. It is suggested that the pain reliever effect of $C$. spinosa roots could be due to the presence of spermidine alkaloids which have anti-inflammatory effects [66]. Similarly, the lyophilised methanolic extracts from flowering buds of $C$. spinosa was also reported to exhibit anti-inflammatory effect by reducing the production of reactive oxygen species (ROS), nitric oxide (NO) and prostaglandins (PGE 2 ) induced by IL-1 $\beta$ on human chondrocytes [74]. These findings were consistent with another study by Feng et al. [75] who demonstrated that the fraction eluted by ethanol-water (50:50, $v / v)$ from C. spinosa fruits was shown to exhibit the most significant anti-arthritic response in male Wistar rats, providing additional evidence that $C$. spinosa possesses anti-inflammatory effects.

Similarly, C. spinosa exhibited anti-inflammatory activity to suppress cytokine production of dendritic cells (DC), induced by lipopolysaccharide (LPS). In a study investigating the effect of C. spinosa fruit ethanol extracts on the maturation of mouse bone marrow-derived DC Hamuti et al. [67] reported that different types of C. spinosa extracts exhibited different effects on the maturation of DC. DC is the key regulator in many aspects in homeostasis of immune system [76] and inflammatory skin disorders [77]. These different types of C. spinosa extracts were labelled as C. spinosa extract (CSE) 2 water (W), CSE middle-layered isolated (M) W, CSE3W, CSE2 dimethyl sulfoxide (D), CSEMD and CSE3D according to their methods of preparation which were either dissolving in water or dimethyl sulfoxide (DMSO) at a concentration of $200 \mathrm{mg} / \mathrm{mL}$. The authors reported that CSEMD and CSEMW dose-dependently increased the expression of cluster of differentiation (CD) 40, CD80 and CD86 [67]. CSE2W was shown to significantly increase the expression of CD40 but not CD80 [67]. Although CSE3D and CSE3W had significantly inhibited the secretions of pro-inflammatory cytokines including IL-1 $\beta$, IL-12p40, IL-6 and tumor necrosis factor (TNF)- $\gamma$ induced by LPS, CSE3D had a higher inhibitory activity than CSE3W [67].

\subsection{Antihepatotoxic}

A study by Gadgoli and Mishra [51] evaluated the effects of C. spinosa on the antihepatotoxic on rats against paracetamol and carbontetrachloride induced toxicity in vivo. In addition, the authors also investigated the effects of $C$. spinosa on galactosamine and thioacetamide induced toxicities in vitro [51]. In their study, methanol soluble fraction of the aqueous extract of aerial parts of $C$. spinosa was reported to exhibit significant reductions in serum glutamyl pyruvate transaminase (SGPT), serum glutamyl oxalacetate transaminase (SGOT), alkaline phosphatase and total bilirubin in paracetamol and carbontetrachloride induced hepatotoxicity in albino rats of Wistar strain [51]. In addition, the authors also reported that aerial parts of $C$. spinosa showed significant anti-hepatotoxic activity in galactosamine and thioacetamide induced hepatotoxicity in isolated rat hepatocytes [51].

Kazemian et al. [68] reported that both groups of diabetic rats receiving $0.2 \mathrm{~g} / \mathrm{kg}$ and $0.4 \mathrm{~g} / \mathrm{kg}$ of hydroalcoholic extract of $C$. spinosa had a significant reduction of alanine aminotransferase (ALT) and alkaline phosphatase (ALP) ( $p<0.05$ for both groups) after 4 weeks of treatment. Therefore, it is suggested that $C$. spinosa extract does not cause any toxic effect on the liver [68]. 


\subsection{Other Pharmacological Properties}

C. spinosa also exhibits potential protective effects against cognitive impairment. In a study investigating the effect of $C$. spinosa on the learning and memory damage induced by chronic administration of LPS $(175 \mu \mathrm{g} / \mathrm{kg})$ in young male Sprague-Dawley rats, Goel et al. [78] reported that the aqueous extract of $C$. spinosa buds had significantly reduced the neurodegeneration in the first region in the hippocampal circuit (CA1) region of hippocampus, suggesting that $C$. spinosa could be used to treat cognitive disorders.

In addition, another study by Mohebali et al. [79] reported that the expression of $\beta$-secretase enzyme (BACE)-1, presenilin protein (PSEN)-1 and PSEN-2 and amyloid precursor protein (APP) genes were significantly down regulated in amyloidogenic related genes in amyloid-beta (A $\beta$ ) peptide-injected Wister albino rats treated with hydroalcoholic extracts of $C$. spinosa leaves and fruits as compared to the control group. Another study by Turgut et al. [80] reported that the extracts of C. spinosa seeds significantly protected against the damage of DNA bands and attenuated cognitive impairment induced by D-galactose in male, Bagg albino, laboratory-bred strain of the House Mouse $(\mathrm{BALB} / \mathrm{c})$ mice. Chronic neurodegenerative diseases such as Alzheimer's disease are associated with the aggregation and misfolding of proteins. The accumulation of $A \beta$ peptide is the key protein involved in the development of Alzheimer's disease and the accumulation of $A \beta$ peptide can be caused by malfunction in $\beta$ - and $\gamma$ - secretase enzymes. BACE is encoded by BACE- $1 ; \gamma$-secretase enzyme is encoded by PSEN-1 and PSEN-2 [81].

C. spinosa also exhibits inhibitory effects on human immunodeficiency virus (HIV)-1 reverse transcriptase [82]. Lam and $\mathrm{Ng}$ [82] isolated a protein with an $\mathrm{N}$-terminal amino acid sequence from the seeds of $C$. spinosa that inhibited HIV-1 reverse transcriptase. The protein exhibited some similarly to imidazoleglycerol phosphate synthase [82]. Lam and $\mathrm{Ng}$ [82] reported that the protein possessed HIV-1 reverse transcriptase inhibitory activity with the half maximal inhibitory concentration $\left(\mathrm{IC}_{50}\right)$ of $0.23 \mu \mathrm{M}$. It is suggested that the inhibition is due to the protein-protein interaction which causes homologous retroviral reverse transcriptase to be inhibited by HIV-protease [82].

\subsection{Adverse Effects}

Currently, the consumption of $C$. spinosa is not associated with any adverse effects according to the published literature, providing evidence that C. spinosa is safe to consume [83].

\section{Conclusions}

A literature review has highlighted that $C$. spinosa exhibits important pharmacological effects because $C$. spinosa is rich in many bioactive compounds including flavonoids. Therefore, given the few clinical studies cited, it is very risky to highlight the potential role of $C$. spinosa on treatment such as diabetes, hypertension and obesity. This suggests that there are many opportunities for the food and healthcare industry to explore the health benefits of $C$. spinosa because there is a potential growth market for $C$. spinosa. However, the majority of the studies that reported beneficial effects of $C$. spinosa on health are animal-based studies. Moreover, these studies used different parts of C. spinosa plant, types of solvents and methods of preparation, which cause the evaluation of activity of C. spinosa difficult. In addition, these studies involve quite heterogeneous data.

Therefore, future prospective research should screen for individual polyphenol constituents that possess health-promoting properties in C. spinosa. This is because a cause-effect relationship between C. spinosa and its health effects can only be established when the composition of C. spinosa is properly characterised and standardised. In addition, there is limited evidence of randomized controlled trials on humans to support such health beneficial effects of $C$. spinosa when compared to other plants such as walnuts that have high economic interests to the food industry. The underlying mechanism influencing human health by the consumption of $C$. spinosa still remains unclear. The effect of shortand long-term consumption of $C$. spinosa on human health therefore needs to be further evaluated. 
Furthermore, the role of the gut microbiota in the degradation of polyphenolic compounds present in the plant has not been considered. This aspect should be put forward in the perspectives [84].

Acknowledgments: Zheng Feei Ma would like to thank Peng Keong Ma, Siew Poh Tan and Zheng Xiong Ma for their active encouragement and support of this work. The authors received no specific funding for this work.

Author Contributions: Z.F.M. wrote the first draft of the paper. Z.F.M and H.Z. revised the paper.

Conflicts of Interest: The authors declare no conflict of interest.

\section{References}

1. Locatelli, C.; Melucci, D.; Locatelli, M. Toxic metals in herbal medicines. A review. Curr. Bioact. Compd. 2014, 10, 181-188. [CrossRef]

2. World Health Organization (WHO). Regulatory Situation of Herbal Medicines: A Worldwide Review; World Health Organization (WHO): Geneva, Switzerland, 2013.

3. Locatelli, M.; Zengin, G.; Uysal, A.; Carradori, S.; De Luca, E.; Bellagamba, G.; Aktumsek, A.; Lazarova, I. Multicomponent pattern and biological activities of seven asphodeline taxa: Potential sources of natural-functional ingredients for bioactive formulations. J. Enzyme Inhib. Med. Chem. 2017, 32, 60-67. [CrossRef] [PubMed]

4. Gunjan, M.; Naing, T.W.; Saini, R.S.; Ahmad, A.; Naidu, J.R.; Kumar, I. Marketing trends \& future prospects of herbal medicine in the treatment of various disease. World J. Pharm. Res. 2015, 4, 132-155.

5. Hall, J.C.; Sytsma, K.J.; Iltis, H.H. Phylogeny of Capparaceae and Brassicaceae based on chloroplast sequence data. Am. J. Bot. 2002, 89, 1826-1842. [CrossRef] [PubMed]

6. Ao, M.; Gao, Y.; Yu, L. Advances in studies on constituents and their pharmacological activities of Capparis spinosa. Chin. Tradit. Herb. Drug 2007, 38, 463-467.

7. Asl, M.B.; Talebpour, A.H.; Alijanpour, R. Introducing of medicinal plants in Maragheh, Eastern Azerbaijan province (northwestern Iran). J. Med. Plants Res. 2012, 6, 4208-4220.

8. Tlili, N.; Elfalleh, W.; Saadaoui, E.; Khaldi, A.; Triki, S.; Nasri, N. The caper (Capparis L.): Ethnopharmacology, phytochemical and pharmacological properties. Fitoterapia 2011, 82, 93-101. [CrossRef] [PubMed]

9. Barbera, G.; Di Lorenzo, R. The caper culture in Italy. Acta Hortic. 1984, 144, 167-171. [CrossRef]

10. Ramezani-Gask, M.; Bahrani, M.J.; Shekafandeh, A.; Salehi, H.; Taghvaei, M.; Al-Ahmadi, M.J. A comparison of different propagation methods of common caper-bush (Capparis spinosa L.) as a new horticultural crop. Int. J. Plant Dev. Biol. 2008, 2, 106-110.

11. Inocencio, C.; Rivera, D.; Alcaraz, F.; Tomás-Barberán, F.A. Flavonoid content of commercial capers (Capparis spinosa, C. Sicula and C. Orientalis) produced in Mediterranean countries. Eur. Food Res. Technol. 2000, 212, 70-74. [CrossRef]

12. Nabavi, S.F.; Maggi, F.; Daglia, M.; Habtemariam, S.; Rastrelli, L.; Nabavi, S.M. Pharmacological effects of Capparis spinosa L. Phytother. Res. 2016, 30, 1733-1744. [CrossRef] [PubMed]

13. Chedraoui, S.; Abi-Rizk, A.; El-Beyrouthy, M.; Chalak, L.; Ouaini, N.; Rajjou, L. Capparis spinosa L. in a systematic review: A xerophilous species of multi values and promising potentialities for agrosystems under the threat of global warming. Front. Plant Sci. 2017, 8, 1845. [CrossRef] [PubMed]

14. Fici, S. A taxonomic revision of the Capparis spinosa group (Capparaceae) from the Mediterranean to Central Asia. Phytotaxa 2014, 174, 1-24. [CrossRef]

15. Fici, S. A taxonomic revision of the Capparis spinosa group (Capparaceae) from eastern Africa to Oceania. Phytotaxa 2015, 203, 24-36. [CrossRef]

16. Aichi-Yousfi, H.; Bahri, B.A.; Medini, M.; Rouz, S.; Nejib Rejeb, M.; Ghrabi-Gammar, Z. Genetic diversity and population structure of six species of Capparis in Tunisia using AFLP markers. C. R. Biol. 2016, 339, 442-453. [CrossRef] [PubMed]

17. Sakcali, M.; Bahadir, H.; Ozturk, M. Ecophysiology of Capparis spinosa L.: A plant suitable for combating desertification. Pak. J. Bot. 2008, 40, 1481-1486.

18. Özdemir, F.; Öztürk, M. Studies on the autecology of Capparis L. Species distributed in west Anatolia. Turk. J. Bot. 1996, 20, 117-127.

19. Rhizopoulou, S.; Psaras, G.K. Development and structure of drought-tolerant leaves of the Mediterranean shrub Capparis spinosa L. Ann. Bot. 2003, 92, 377-383. [CrossRef] [PubMed] 
20. Mansour, R.B.; Jilani, I.B.H.; Bouaziz, M.; Gargouri, B.; Elloumi, N.; Attia, H.; Ghrabi-Gammar, Z.; Lassoued, S. Phenolic contents and antioxidant activity of ethanolic extract of Capparis spinosa. Cytotechnology 2016, 68, 135-142. [CrossRef] [PubMed]

21. Afzal, S.; Afzal, N.; Awan, M.R.; Khan, T.S.; Khanum, A.G.; Tariq, S. Ethno-botanical studies from northern Pakistan. J. Ayub. Med. Coll. Abbottabad. 2009, 21, 52-57. [PubMed]

22. Mahboubi, M.; Mahboubi, A. Antimicrobial activity of Capparis spinosa as its usages in traditional medicine. Herba Pol. 2014, 60, 39-48. [CrossRef]

23. Fu, X.P.; Aisa, H.A.; Abdurahim, M.; Yili, A.; Aripova, S.F.; Tashkhodzhaev, B. Chemical composition of Capparis spinosa fruit. Chem. Nat. Compd. 2007, 43, 181-183. [CrossRef]

24. Çaliş, İ.; Kuruüzüm, A.; Lorenzetto, P.A.; Ruedi, P. (6S)-hydroxy-3-oxo- $\alpha$-ionol glucosides from Capparis spinosa fruits. Phytochemistry 2002, 59, 451-457. [CrossRef]

25. Çaliş, İ; Kuruüzüm, A.; Rüedi, P. 1H-Indole-3 acetonitrile glycosides from Capparis spinosa fruits. Phytochemistry 1999, 50, 1205-1208. [CrossRef]

26. Zhou, H.; Jian, R.; Kang, J.; Huang, X.; Li, Y.; Zhuang, C.; Yang, F.; Zhang, L.; Fan, X.; Wu, T.; et al. Anti-inflammatory effects of caper (Capparis spinosa L.) fruit aqueous extract and the isolation of main phytochemicals. J. Agric. Food Chem. 2010, 58, 12717-12721. [CrossRef] [PubMed]

27. Ramezani, Z.; Aghel, N.; Keyghobadi, H. Rutin from different parts of Capparis spinosa growing wild in Khuzestan/Iran. Pak. J. Biol. Sci. 2008, 11, 768-772. [CrossRef] [PubMed]

28. Rodrigo, M.; Lazaro, M.J.; Alvarruiz, A.; Giner, V. Composition of capers (Capparis spinosa): Influence of cultivar, size and harvest date. J. Food Sci. 1992, 57, 1152-1154. [CrossRef]

29. Siracusa, L.; Kulisic-Bilusic, T.; Politeo, O.; Krause, I.; Dejanovic, B.; Ruberto, G. Phenolic composition and antioxidant activity of aqueous infusions from Capparis spinosa L. and Crithmum maritimum L. before and after submission to a two-step in vitro digestion model. J. Agric. Food Chem. 2011, 59, 12453-12459. [CrossRef] [PubMed]

30. Sharaf, M.; El-Ansari, M.A.; Saleh, N.A.M. Quercetin triglycoside from Capparis spinosa. Fitoterapia 2000, 71, 46-49. [CrossRef]

31. Afsharypuor, S.; Jeiran, K.; Jazy, A.A. First investigation of the flavour profiles of the leaf, ripe fruit and root of Capparis spinosa var. Mucronifolia from Iran. Pharm. Acta Helv. 1998, 72, 307-309. [CrossRef]

32. Khatib, M.; Pieraccini, G.; Innocenti, M.; Melani, F.; Mulinacci, N. An insight on the alkaloid content of Capparis spinosa L. root by HPLC-DAD-MS, MS/MS and ${ }^{1} \mathrm{H}$ qNMR. J. Pharm. Biomed. Anal. 2016, 123, 53-62. [CrossRef] [PubMed]

33. Boga, C.; Forlani, L.; Calienni, R.; Hindley, T.; Hochkoeppler, A.; Tozzi, S.; Zanna, N. On the antibacterial activity of roots of Capparis spinosa L. Nat. Prod. Res. 2011, 25, 417-421. [CrossRef] [PubMed]

34. Akgül, A.; Özcan, M. Some compositional characteristics of capers (Capparis spp.) seed and oil. Grasas y Aceites 1999, 50, 49-52. [CrossRef]

35. Gupta, S.A.; Chakrabarty, M.M. Composition of the seed fats of the Capparidaceae family. J. Sci. Food Agric. 1964, 15, 69-73. [CrossRef]

36. Matthaus, B.; Ozcan, M. Glucosinolates and fatty acid, sterol, and tocopherol composition of seed oils from Capparis spinosa Var. spinosa and Capparis ovata Desf. Var. canescens (Coss.) Heywood. J. Agric. Food Chem. 2005, 53, 7136-7141. [PubMed]

37. Mollica, A.; Zengin, G.; Locatelli, M.; Stefanucci, A.; Mocan, A.; Macedonio, G.; Carradori, S.; Onaolapo, O.; Onaolapo, A.; Adegoke, J.; et al. Anti-diabetic and anti-hyperlipidemic properties of Capparis spinosa L.: In vivo and in vitro evaluation of its nutraceutical potential. J. Funct. Foods 2017, 35, 32-42. [CrossRef]

38. Vahid, H.; Rakhshandeh, H.; Ghorbani, A. Antidiabetic properties of Capparis spinosa L. and its components. Biomed. Pharmacother. 2017, 92, 293-302. [CrossRef] [PubMed]

39. Tlili, N.; Khaldi, A.; Triki, S.; Munné-Bosch, S. Phenolic compounds and vitamin antioxidants of caper (Capparis spinosa). Plant Foods Hum. Nutr. 2010, 65, 260-265. [CrossRef] [PubMed]

40. Dekanski, D.; Ristić, S.; Radonjić, N.V.; Petronijević, N.D.; Dekanski, A.; Mitrović, D.M. Olive leaf extract modulates cold restraint stress-induced oxidative changes in rat liver. J. Serb. Chem. Soc. 2011, 76, 1207-1218. [CrossRef]

41. Nijveldt, R.J.; van Nood, E.; van Hoorn, D.E.; Boelens, P.G.; van Norren, K.; van Leeuwen, P.A. Flavonoids: A review of probable mechanisms of action and potential applications. Am. J. Clin. Nutr. 2001, 74, 418-425. [PubMed] 
42. Korkmaz, A.; Kolankaya, D. Protective effect of rutin on the ischemia/reperfusion induced damage in rat kidney. J. Surg. Res. 2010, 164, 309-315. [CrossRef] [PubMed]

43. Milde, J.; Elstner, E.F.; Grassmann, J. Synergistic inhibition of low-density lipoprotein oxidation by rutin, gamma-terpinene, and ascorbic acid. Phytomedicine 2004, 11, 105-113. [CrossRef] [PubMed]

44. Gupta, A.; Birhman, K.; Raheja, I.; Sharma, S.K.; Kar, H.K. Quercetin: A wonder bioflavonoid with therapeutic potential in disease management. Asian Pac. J. Trop. Dis. 2016, 6, 248-252. [CrossRef]

45. Yang, T.; Wang, C.; Chou, G.; Wu, T.; Cheng, X.; Wang, Z. New alkaloids from Capparis spinosa: Structure and X-ray crystallographic analysis. Food Chem. 2010, 123, 705-710. [CrossRef]

46. Zhang, S.; Hu, D.B.; He, J.B.; Guan, K.Y.; Zhu, H.J. A novel tetrahydroquinoline acid and a new racemic benzofuranone from Capparis spinosa $\mathrm{L}$., a case study of absolute configuration determination using quantum methods. Tetrahedron 2014, 70, 869-873. [CrossRef]

47. Zhou, H.F.; Xie, C.; Jian, R.; Kang, J.; Li, Y.; Zhuang, C.L.; Yang, F.; Zhang, L.L.; Lai, L.; Wu, T.; et al. Biflavonoids from caper (Capparis spinosa L.) fruits and their effects in inhibiting NF-kappa B activation. J. Agric. Food Chem. 2011, 59, 3060-3065. [CrossRef] [PubMed]

48. Sharaf, M.; El-Ansari, M.A.; Saleh, N.A.M. Flavonoids of four cleome and three Capparis species. Biochem. Syst. Ecol. 1997, 25, 161-166. [CrossRef]

49. Matthaus, B.; Ozcan, M. Glucosinolate composition of young shoots and flower buds of capers (Capparis species) growing wild in turkey. J. Agric. Food Chem. 2002, 50, 7323-7325. [CrossRef] [PubMed]

50. Yu, Y.; Gao, H.; Tang, Z.; Song, X.; Wu, L. Several phenolic acids from the fruit of Capparis spinosa. Asian J. Tradit. Med. 2006, 1, 101-104.

51. Gadgoli, C.; Mishra, S.H. Antihepatotoxic activity of $p$-methoxy benzoic acid from Capparis spinosa. J. Ethnopharmacol. 1999, 66, 187-192. [CrossRef]

52. Ascrizzi, R.; Cioni, P.L.; Giusti, G.; Pistelli, L.; Flamini, G. Patterns in volatile emission of different aerial parts of caper (Capparis spinosa L.). Chem. Biodivers. 2016, 13, 904-912. [CrossRef] [PubMed]

53. Fu, X.P.; Wu, T.; Abdurahim, M.; Su, Z.; Hou, X.L.; Aisa, H.A.; Wu, H. New spermidine alkaloids from Capparis spinosa roots. Phytochem. Lett. 2008, 1, 59-62. [CrossRef]

54. Ma, Z.F.; Zhang, H. Phytochemical constituents, health benefits, and industrial applications of grape seeds: A mini-review. Antioxidants 2017, 6, 71. [CrossRef] [PubMed]

55. Ma, Z.F.; Lee, Y.Y. Virgin coconut oil and its cardiovascular health benefits. Nat. Prod. Commun. 2016, 11, 1151-1152.

56. Willett, W.C. Dietary fats and coronary heart disease. J. Intern. Med. 2012, 272, 13-24. [CrossRef] [PubMed]

57. Eddouks, M.; Lemhadri, A.; Michel, J.B. Hypolipidemic activity of aqueous extract of Capparis spinosa L. in normal and diabetic rats. J. Ethnopharmacol. 2005, 98, 345-350. [CrossRef] [PubMed]

58. Lemhadri, A.; Eddouks, M.; Sulpice, T.; Burcelin, R. Anti-hyperglycaemic and anti-obesity effects of Capparis spinosa and Chamaemelumnobile aqueous extracts in HFD mice. Am. J. Pharmacol. Toxicol. 2007, 2, 106-110.

59. Huseini, H.F.; Hasani-Rnjbar, S.; Nayebi, N.; Heshmat, R.; Sigaroodi, F.K.; Ahvazi, M.; Alaei, B.A.; Kianbakht, S. Capparis spinosa L. (caper) fruit extract in treatment of type 2 diabetic patients: A randomized double-blind placebo-controlled clinical trial. Complement. Ther. Med. 2013, 21, 447-452. [CrossRef] [PubMed]

60. Jalali, M.T.; Mohammadtaghvaei, N.; Larky, D.A. Investigating the effects of Capparis spinosa on hepatic gluconeogenesis and lipid content in streptozotocin-induced diabetic rats. Biomed. Pharmacother. 2016, 84, 1243-1248. [CrossRef] [PubMed]

61. Ali, Z.N.; Eddouks, M.; Michel, J.B.; Sulpice, T.; Hajji, L. Cardiovascular effect of Capparis spinosa aqueous extract. Part III: Antihypertensive effect in spontaneously hypertensive rats. Am. J. Pharmacol. Toxicol. 2007, 2, 111-115. [CrossRef]

62. Gull, T.; Sultana, B.; Bhatti, I.A.; Jamil, A. Antibacterial potential of Capparis spinosa and Capparis decidua extracts. Int. J. Agric. Biol. 2015, 17, 727-733. [CrossRef]

63. Masadeh, M.M.; Alkofahi, A.S.; Alzoubi, K.H.; Tumah, H.N.; Bani-Hani, K. Anti-Helicobactor pylori activity of some jordanian medicinal plants. Pharm. Biol. 2014, 52, 566-569. [CrossRef] [PubMed]

64. El Azhary, K.; Tahiri Jouti, N.; El Khachibi, M.; Moutia, M.; Tabyaoui, I.; El Hou, A.; Achtak, H.; Nadifi, S.; Habti, N.; Badou, A. Anti-inflammatory potential of Capparis spinosa L. in vivo in mice through inhibition of cell infiltration and cytokine gene expression. BMC Complement. Altern. Med. 2017, 17, 81. [CrossRef] [PubMed] 
65. Moutia, M.; Azhary, K.; Elouaddari, A.; Jahid, A.; Jamal Eddine, J.; Seghrouchni, F.; Habti, N.; Badou, A. Capparis spinosa L. promotes anti-inflammatory response in vitro through the control of cytokine gene expression in human peripheral blood mononuclear cells. BMC Immunol. 2016, 17, 26. [CrossRef] [PubMed]

66. Maresca, M.; Micheli, L.; Di Cesare Mannelli, L.; Tenci, B.; Innocenti, M.; Khatib, M.; Mulinacci, N.; Ghelardini, C. Acute effect of Capparis spinosa root extracts on rat articular pain. J. Ethnopharmacol. 2016, 193, 456-465. [CrossRef] [PubMed]

67. Hamuti, A.; Li, J.; Zhou, F.; Aipire, A.; Ma, J.; Yang, J.; Li, J. Capparis spinosa fruit ethanol extracts exert different effects on the maturation of dendritic cells. Molecules 2017, 22, 97. [CrossRef] [PubMed]

68. Kazemian, M.; Abad, M.; Haeri, M.R.; Ebrahimi, M.; Heidari, R. Anti-diabetic effect of Capparis spinosa L. root extract in diabetic rats. Avicenna J. Phytomed. 2015, 5, 325-332. [PubMed]

69. Ness, G.C. Physiological feedback regulation of cholesterol biosynthesis: Role of translational control of hepatic HMG-CoA reductase and possible involvement of oxylanosterols. Biochim. Biophys. Acta 2015, 1851, 667-673. [CrossRef] [PubMed]

70. Iwaniak, A.; Minkiewicz, P.; Darewicz, M. Food-originating ACE inhibitors, including antihypertensive peptides, as preventive food components in blood pressure reduction. Compr. Rev. Food Sci. Food Saf. 2014, 13, 114-134. [CrossRef]

71. Mazarei, F.; Jooyandeh, H.; Noshad, M.; Hojjati, M. Polysaccharide of caper (Capparis spinosa L.) leaf: Extraction optimization, antioxidant potential and antimicrobial activity. Int. J. Biol. Macromol. 2017, 95, 224-231. [CrossRef] [PubMed]

72. Mahasneh, A.M. Screening of some indigenous Qatari medicinal plants for antimicrobial activity. Phytother. Res. 2002, 16, 751-753. [CrossRef] [PubMed]

73. Ma, Z.F.; Majid, N.A.; Yamaoka, Y.; Lee, Y.Y. Food allergy and Helicobacter pylori infection: A systematic review. Front. Microbiol. 2016, 7, 368. [CrossRef] [PubMed]

74. Panico, A.; Cardile, V.; Garufi, F.; Puglia, C.; Bonina, F.; Ronsisvalle, G. Protective effect of Capparis spinosa on chondrocytes. Life Sci. 2005, 77, 2479-2488. [CrossRef] [PubMed]

75. Feng, X.; Lu, J.; Xin, H.; Zhang, L.; Wang, Y.; Tang, K. Anti-arthritic active fraction of Capparis spinosa L. fruits and its chemical constituents. Yakugaku Zasshi 2011, 131, 432-439. [CrossRef]

76. Tel, J.; Benitez-Ribas, D.; Janssen, E.M.; Smits, E.L.J.; Jacobs, J.F.M. Dendritic cells as vaccines: Key regulators of tolerance and immunity. Mediators Inflamm. 2016, 2016, 5789725. [CrossRef] [PubMed]

77. Chu, C.C.; Di Meglio, P.; Nestle, F.O. Harnessing dendritic cells in inflammatory skin diseases. Semin. Immunol. 2011, 23, 28-41. [CrossRef] [PubMed]

78. Goel, A.; Digvijaya; Garg, A.; Kumar, A. Effect of Capparis spinosa Linn. extract on lipopolysaccharide-induced cognitive impairment in rats. Indian J. Exp. Biol. 2016, 54, 126-132. [PubMed]

79. Mohebali, N.; Shahzadeh Fazeli, S.A.; Ghafoori, H.; Farahmand, Z.; MohammadKhani, E.; Vakhshiteh, F.; Ghamarian, A.; Farhangniya, M.; Sanati, M.H. Effect of flavonoids rich extract of Capparis spinosa on inflammatory involved genes in amyloid-beta peptide injected rat model of Alzheimer's disease. Nutr. Neurosci. 2016, 21, 143-150. [CrossRef] [PubMed]

80. Turgut, N.H.; Kara, H.; Arslanbas, E.; Mert, D.G.; Tepe, B.; Gungor, H. Effect of Capparis spinosa L. on cognitive impairment induced by D-galactose in mice via inhibition of oxidative stress. Turk. J. Med. Sci. 2015, 45, 1127-1136. [CrossRef] [PubMed]

81. Majd, S.; Power, J.H.; Grantham, H.J.M. Neuronal response in Alzheimer's and Parkinson's disease: The effect of toxic proteins on intracellular pathways. BMC Neurosci. 2015, 16, 69. [CrossRef] [PubMed]

82. Lam, S.K.; Ng, T.B. A protein with antiproliferative, antifungal and HIV-1 reverse transcriptase inhibitory activities from caper (Capparis spinosa) seeds. Phytomedicine 2009, 16, 444-450. [CrossRef] [PubMed]

83. Sher, H.; Alyemeni, M.N. Ethnobotanical and pharmaceutical evaluation of Capparis spinosa L., validity of local folk and unani system of medicine. J. Med. Plants Res. 2010, 4, 1751-1756.

84. Espin, J.C.; Gonzalez-Sarrias, A.; Tomas-Barberan, F.A. The gut microbiota: A key factor in the therapeutic effects of (poly)phenols. Biochem. Pharmacol. 2017, 139, 82-93. [CrossRef] [PubMed]

(C) 2018 by the authors. Licensee MDPI, Basel, Switzerland. This article is an open access article distributed under the terms and conditions of the Creative Commons Attribution (CC BY) license (http:/ / creativecommons.org/licenses/by/4.0/). 